\title{
Investigating the Service Friendship, Communicational Skills and Personality Traits in High-contact Service
}

\author{
Bahman Hajipour \\ Associate in management, Faculty of Economy and social science \\ Shahid Chamran University, Ahwaz, Iran \\ E-mail: Bhajipour@suc.ac.ir
}

Belghase Bavarsad

Assistant Professor in management, Faculty of Economy and social science

Shahid Chamran University, Ahwaz, Iran

E-mail: bita40@yahoo.com

Zahra Asadi (corresponding author)

M.S in marketing management, Faculty of Economy and social science

Shahid Chamran University, Ahwaz, Iran

Tel: +98-93-761-14869_E-mail: Zahra_hamid2@yahoo.com

Received: Dec. 7, 2012 Accepted: December 29, 2012 Published: January 1, 2013

doi:10.5296/jmr.v5i1.2824

URL: http://dx.doi.org/10.5296/jmr.v5i1.2824

\begin{abstract}
Service providing by customers' preserving and satisfaction is one of the basic tools of service organizations survival in today's competitive environment. The high-contact service is not an exception of this principle. One of the fields which can be used remarkably in order to preserve and satisfy the customer in these kinds of service is the service friendship between the service provider and the customers. In the present study, the relationship among the customers' Personality traits, communicational skills of the high-contact service providers, and the service friendship has been investigated. The sample of the study includes 345 customers of counseling and medical service of Isfahan which 191 were females, and 154 were males. The effect of the extroversion variables and sociability on the communicational
\end{abstract}


skills and communicational skills effects on the friendship service, and also the effect of the friendship service on the satisfaction and anticipation of future interaction have been investigated. The data analysis has been done using Lisrel 8.5. The results indicate that the extroversion variables have affected the communicational skills, the communicational skills affected the friendship service, friendship service affected the satisfaction, and satisfaction affected the anticipation of the future interaction in a significant positive way. However, the significance effect of the sociability on the communicational skills and the friendship service effects on the anticipation of the future interaction have been rejected.

Keywords: Personality Traits, Communicational Skills, Service Friendship, High-Contact Service 


\section{Macrothink}

\section{Introduction}

Lovelock and Wright have defined high-contact service as a service with a high degree of interaction with the service provider (both physically and mentally). The high-contact service is divided into 2 parts of communication with equipment and the part of communication with a party. Boven, Kellog and Chase have defined the high-contact service as a service with the high degree of communication with the service provider. The present study has emphasized on the communication of the service provider and the customer and based on this matter $f$ the viewpoint of Boven, Kellog and Chase has been applied (Kinard \& L. Capella, 2006; Lovelock \& Wright, 2003; Chris Linn \& Hsieh, 2011).

Since the high-contact services are kinds of the services in which the contact of the service provider with the customer is in a high level, and a great deal of interaction is occurred one of the most important factors in the success of high-contact services is the friend service between customers and the service providers. The friendship service in high-contact service has been defined as Personal relationship containing intimacy and the closeness feeling of the customer to the service provider. Creating a high level of intimacy by the service providers make them the social supporters of the customers (Chris Linn \& Hsieh, 2011).

By understanding the mechanism and the conditions which affect the friendship service, the attempts towards the friendship service can be targeted in a better way and through this the customer's satisfaction and preserving is attained sufficiently. In the high-contact services which are the complicated and bespoken services and the number of such interaction is high, the friendship service between the service provider and the customer for customer's satisfaction and preserving plays a crucial role.

One of the most effective factors on establishing the friendship service between customers and service providers of high-contact services is the communicational skills of the high-contact service of the service providers (Chris Linn \& Hsieh, 2011).

\section{Conceptual background}

\subsection{Communicational skills}

The effective social interactions are dependent on the effective application of the communicational skills. The communicational skills as the micro processes enable the individual to behave in a way that others see him/her as a righteous person. The people with the communicational skills can sympathize with their addressees, get the others' confirmation for themselves, and listen to their addressees carefully (Leite et al, 2005). The major communicational skills which lead to establishing an effective communication are:

\subsubsection{Verbal skill}

Verbal skill is the conscious application of the verbal symbols to persuade others to do the works. The psychologists believed unanimously that through the language the man will change. The verbal communication is important because it is one of the essential tools for the service providers of high-contact service to be effective on their customers. Among all of the things that the high-contact service providers do, speaking is the first. In fact, when the 


\section{Macrothink Institute ${ }^{\mathrm{TM}}$}

high-contact service provider is doing his/her job, the most important aspect of his/her profession is that they could operate the verbal environment sufficiently (Griffith, 1999). The verbal skills are necessary for the high-contact service providers, and they should try to make their speech and prescriptions understandable and also not ambiguous (Berko, 1998).

\subsubsection{Listening Skill}

For effective listening different definitions have been proposed which are:

1. Active participation in a conversation

2. An active process which includes attention, understanding, evaluation, reminding, and responding (Mehraban, 2000).

The effective listening is the foundation of an effective communication. The art of good listening extends the quality of communication with the customers and enables the high-contact service providers to get the customers' affection, cooperation, empathy, and consultation (Allen \& Blackburn, 1989).

\subsubsection{Feedback skill}

Vicente and Waldron state that the messages which are backing from the recipient to the sender are called feedback. It is hard to know, without the feedback, that whether the message is gotten and understood or not (Vicente \& Waldron, 1991). Feedback brings more understanding between the service provider and the customers. Feedback giving by the service provider to the customers has two advantages:

1. The criterion of communication success process

2. Messages interpretation or correction(alagheman, 1999)

The communicational skills are the key and essential elements in high-contact service professions, because establishing the effective communication eliminates the emotions and thoughts showing of the customer and also is followed by obeying the treatment orders. The communicational skills increase the customers' trust and satisfaction (Shaw, 2006).

Effective communications between customers and service providers not only affect the customers' obedience of the service providers' orders but also decrease the official complaint against the service providers. Effective communication with the customer increases the required cares of the customer. In getting the customer's memoir and his/her last treatment program is highly effective (Howell et al, 2006). The effective communications between the customers and service provider facilitates the treatment process and causes the right decision making by service provider (DiMatteo, 1994). In addition on the effects of all communicational skills, their direct impact on the development of friendly relations between the customer and service providing is wonderful.

Fortunately, the required communicational skills for establishing the effective communications between the customer and service provider are teachable, learnable, and practicable for the high-contact service providers (Lolli, 2012). One of the cases which 
should be taught to the service providers is that the customer's personal traits are very effective in establishing the successful communication with them.

\subsection{Customers' Personality traits}

Personality is referred to a set of characteristics and traits which are the behavioral knowledge of the individual. These characteristics include thought, emotions, and self-understanding of the individual, ideas phase, the way of thinking and many other habits (Behzadjazi, 2008). Personality traits are the characteristics and attributions which emerge in various situations, have a relative stability, different from person to person, and can be measured (Nazarpour, 2005).

The traits and factors theory is one of the most applied theories in identifying the personal traits in the marketing realm. This theory states that: the personality is a combination of the personal traits which every trait inclines a specific way of responding (Barrett \& Pietromonaco, 1997). This theory is fixed based on the four following hypotheses: 1 . these traits are the stable traits of the people, 2. people are different in extending these traits, 3 . a few number of common traits are existed in most of the people, and 4. these traits are measured by questionnaire or other instruments of behavior measuring (John \& Robins, 1993).

Among the various tests which are existed for investigating the Personality traits in this field, the Neo test is one of the most valid tests confirmed by many experts (Barret \& Pietromonaco, 1997). This test has been used in different marketing research many times. In this test the Personality traits are classified in five following areas:

- Extroversion

- $\quad$ Openness to the new experiences (being open to new experiences)

- Accountability (conscientiousness)

- $\quad$ Sociability (adaptability)

- Emotional stability (neuroticism)

From the viewpoints of most of the researchers extroversion and sociability have an important role in the customers' behavior (Paul, 1996). Accordingly marketers try to evaluate the customers' reactions to the marketing activities by studying the customers' Personality traits (Matzeler, 2006; Matzeler, 2011). Some of the customers' Personality traits like extroversion and sociability affect their inclination for service providers' communicational skills. Accordingly, in this study two Personality traits of the extroversion and sociability of the customer have been selected to investigate their effects on the service providers' communicational skills. Both traits are explained briefly in the table 1.

The extrovert people are gregarious, affable, energetic, talkative, and sociable people (Ferguson, 2009). They like other people, want the communities and parties, and are active and like communication (Costa \& McCrea, 1992). These traits indicate that they are more successful in communication with others. In the same line, it is said that the extrovert 
customers are more successful than introvert customers in establishing the communication with the high-contact service providers, the service in which high level of communication between the customer and the service provider is established.

\section{Hypothesis 1: the customer's extroversion has a significant positive effect on the service provider's communicational skills.}

Social people are polite, courteous, altruist, and whole-hearted people and they have kind hearts (Ferguson, 2009). These people are enthusiast to help to others and think that others should behave in this way (Zamiri, 1388). These people like the interpersonal positive relationships and the assisting values (Digman, 1990). All of these traits state that the social customers can have a more successful relationship with the high-contact service providers than those people who do not behave in this way. It should be noticed that, the high-contact service is a service in which the contact of the service provider with the customer is high and a lot of interactions and relationships are exchanging between the customer and the service provider. Therefore, in high-contact service the social customers tend to establish a positive relationship with the high-contact service provider. Thus:

\section{Hypothesis 2: customer's sociability has a significant positive effect on the service provider's communicational skills.}

\subsection{Friendship service}

Friendship service in high-contact service is defined as a personal relationship including the intimacy and its feeling by the customer to the service provider. In these relationships a high level of intimacy is produced by the service provider in a way that turns itself to a kind of social supporter for the customers (Chris Linn \& Hsieh, 2001).

Human behavior is a function of reciprocal interactions between the environment and the individual. In high-contact service which is the complicated bespoken service the number of such service is high. Also, these services are more exposed to the social factors than economic interactions. In this way, establishing the friendship service between the service provider and the customer plays a crucial role in successful high-contact service (Chris Linn \& Hsieh, 2001).

As it was mentioned, most of the interactions in high-contact service are social interactions, which motivate the customers to keep the social benefits resulted from these relationships (Goodwin \& Gremler, 1996). These benefits can be produced through the interpersonal social elements and the individual friendship service between the service providers and customers. The interpersonal social elements are the most important components of the friendship service between the customer and service provider which lead to forming an individual obligation. Communicational skills help the service provider to conduct the social to individual elements to a direction for establishing this obligation (Goodwin \& Gremler, 1996).

Once the service provider uses the communicational skills appropriately, the customer feels that the service provider treats as a friend and the customer tries to establish an individual or 
service friendship with the service provider. In fact, the customer retalliates. The service providers' social skills and behaviors lead to developing the positive feeling and understanding the social benefits in the customer. By passing the time, these positive feelings and benefits lead to forming the friendship service between the customer and the service provider (Chris Linn \& Hsieh, 2011).

Hypothesis 3: the social skills of the service providers have a significant positive effect on the friendship service between the service providers and the customer.

In the commercial markets the individual and service friendship between the vendee and the vendor is one of the main introductions to obtain the desirable output for the seller company. Similarly, the service literature states that the social benefits resulted from the interpersonal relationships between the customer and the service provider have a special effect on the outputs and the service (Foster \& Cadogan, 2000).

The close relationships contribute both to the customer and the service provider to reach to a high level of satisfaction. Customer's satisfaction refers to the amount of the positive feeling of the customer about the presented service (Mittal et al, 1998). Gutek (1999) argues that those customers who have a service friendship with the service provider are more satisfied than others who do not have this friendship. The friendship interactions lead to the creation of positive emotional reactions towards the service provider which these reactions help to the customer's satisfaction increasing .Price and Arnold (1993) believe that the friendship relationships between the customer and service provider increase the customer's satisfaction (Chris Linn \& Hsieh, 2011).

Hypothesis 4: the service friendship between the customer and the service provider has a positive significant effect on the customer's satisfaction.

Service friendship between the customer and service provider affects the loyalty of the customer. The effect of the friendship service in the high-contact service which contains a high level of Personal interactions is more. The interpersonal communications help to the social benefits development, desired evaluation of the services and also increasing the customer's satisfaction. The friendship service affects the positive verbal advertisements, customer's loyalty, and the customer's anticipation of future interaction (Chris Linn \& Hsieh, 2011).

Hypothesis 5: the friendship service between the customer and the service provider has a positive significant effect on the anticipation of future interaction.

Kotler (1999) has defined satisfaction, degree of the actual performance of a service provider or product that meets customer expectations. Gamal and Nasser (2002) defined satisfaction, customer positive attitude or Feeling towards a service or product after using it. According to definition of Kotler, Satisfied Customers are met Expectations of the performance of the service and products provided. And according to definition of Gamal Nasser satisfied customers have feel happy and positive attitude to Service provider. Meet expectations and positive attitudes of satisfied customers, they tend to anticipation of future interaction to the service provider (Lovelock, 2002). 


\section{Macrothink

The researches have indicated that there is a relationship between the satisfaction and the anticipation of future interaction. Ramsey and Sohi (1997) believe that the anticipation of future interaction depend on the extent of the experiences of customer's satisfaction in the past (Chris Linn \& Hsieh, 2011).

\section{Hypothesis 6: the customer's satisfaction has a positive significant effect on the anticipation of future interaction.}

Based on the discussed subjects the conceptual model of the research is shown in Figure 1.

\section{Research Methodology}

From the perspective of goal and nature, this study is an applied research and based on the data collection the hypothesis and the conclusion is a descriptive one. Since the data collection instrument is a combination of library studies and field study, it has been conducted in a descriptive-survey manner.

\section{Sample of the study}

For sample selection, it has been tried that the crowded places such as shopping centers, trains and subway stations and etc. be chosen to increase the randomization of the samples increases. The research sample includes all of these service customers which were present at these places at the time of the sampling. In this research the simple random sampling with the unlimited sample at the certainty level of $95 \%$ and the deviation level of $0.06 \%$ the approximate amount of the sample was estimate to be 267 people. For assurance, 400 questionnaires were distributed and among them 365 questionnaires were confirmed .the sample Demographic status are shown in Table 2.

\section{Instrument}

The required data has been collected using a questionnaire containing 39 questions. The related questions to each variable and also the sources are provided in table 3.

For determining the formal and content validity of the questionnaire the researchers and experts' viewpoints related to the study about the degree of the accuracy and clearance of the questionnaires have been taken into account and the validity of the questionnaire was confirmed. Also, for confirming the structure's validity the confirming factor analysis has been used which its results are provided in the factor analysis section. To evaluate the reliability, the Cronbach Alpha has been used. The Alpha Cronbach for each of the variables has been illustrated in table 3 . The inducible factor of the whole questionnaire reported to be 87.4\%. Since the Alpha Cronbach of all variables and the whole questionnaire has been higher than $70 \%$ the questionnaire has a high reliability.

\subsection{The confirming factor analysis}

Regarding the presented indices in table 4, it can be noted that the confirming factor analysis of the model has a sufficient goodness. On the other hand, the standardized factorial loads indicate the high correlation of the observed variable and the investigated factor. According 


\section{Macrothink}

to figure 2, it is clear that the factorial loads are in an acceptable level. So, the correlation between the observed variable and the investigated factor is observable.

\section{Modeling the structural equations}

First of all, the study's hypotheses are stated, after that the modeling models of the structural equations in different positions have been brought, and then the accepting and rejecting of the hypotheses have been done.

\subsection{Model in standard position}

Figure 3 illustrates the research model in the standard position. This model contains the standard coefficients. The digits on the arrows between the variables show the standard coefficients.

\subsection{Model in Significant position}

Figure 4 shows the Research Model in Significant position. In the structural equations model in the standard format no estimation relevant to the hypothesis is done, but in the format of T-value the model parameters' estimation is done which the T-value model can be seen in figure 5. If the amount of $t$ (the amount on each arrow) would be in this interval (-1.96 \& 1.96), it shows that the relevant parameter in the level of $5 \%$ has not a significant difference with zero (Kalantari, 2010).

\subsection{Rejecting and confirming the hypotheses}

Regarding the figures 3, 4, and table.5 it is clear that the reliability of the model is the desirable. Table 7 illustrates the rejection and confirmation of the hypotheses with the significance and standard coefficients. This table shows that the hypotheses $1,3,4$, and 6 are confirmed and hypotheses 2 and 5 have been rejected. It means that, there has been a positive significant effect by extroversion on communicational skills of the service provider, communicational skills on the service friendship, service friendship on the customer's satisfaction, and satisfaction on the anticipation of the future interaction. However, the effect of sociability on the communicational

Skills and service friendship on the anticipation of future interaction has been rejected.

\subsection{Model goodness}

In the table.6 some these indices and their optimized positions will be explained. The relevant numbers to the indices of this model indicates its high goodness.

\section{References}

Alaghemand, A. (1999). school organizational health. Journal of Management in Education and Training (21). persian

Alan, W. R. (1989). Managing organizational behavior (2 ed.). Indiana University: Irwin.

Alayi. Z, e. a. (2011). Relation between communication skills and marital- adaptability among university students. 4. 
Barrett L.F. and Pietromonaco, P. R. (1997). Accuracy of the Five Factor Mode in Predicting Perceptions of Daily Social Interactions. Personalit \& Social Psychology, 23(11), 1173-87. http://dx.doi.org/10.1177/01461672972311005

Behzadjazi, S. (2008). The relationship between communication skills and personal traits esfahan city school manegers at various periods. Master's thesis, khorasgan Islamic Azad University. khorasgan, Master's thesis: Islamic Azad University, persain

Berko, R. W. (1999). Communicating: A Social and Career focous (Orginal work published 1998). (S. A. Trans, Trans.) Tehran: Office of Academic Publishing.

Chris Lin, j. a. (2011). Modeling service friendship and customer compliance in high-contact service relationships. Service Management, 607-631.

Costs, P. T. (1992). Normal personality assessment in clinical practice: The NEO personality inventory, psychological assessment. consulting and oolinicalpsychology, 4, 5-13.

Costs, P. T. (1990). Personalty disorder and the five factor model of personality. personality disorder, 4, 362-377. http://dx.doi.org/10.1521/pedi.1990.4.4.362

Digman, J. M. (1990). Personality structure: Emergence of the five-factor model. Annual Review of Psychology, 417-440. http://dx.doi.org/10.1146/annurev.ps.41.020190.002221

DiMatteo, M. (1994). The physician-patient relationship: effects on the quality of health care, 37, 146-61. http://dx.doi.org/10.1097/00003081-199403000-00019

Ferguson, C... (2009). Research on the effects of violent video games: A critical analysis. Social and Personality Psychology Compass, 3(3), 351-364. http://dx.doi.org/10.1111/j.1751-9004.2009.00175.x

Foster, B. a. (2000). Relationship selling and customer loyalty: an empirical investigation. $\begin{array}{lllll}\text { Marketing Intelligence } \quad \& \quad \text { Planning, } & 18(4),\end{array}$ http://dx.doi.org/10.1108/02634500010333316

Goodwin, C. a. (1996). Friendship over the counter: How social aspects of service encounters influence consumer service loyalty. (T. A. Brown, Ed.) Advances in Services Marketing and Management, 5, 247-82. http://dx.doi.org/10.1016/S1067-5671 (96)05059-7

Griffith, N. (1999). Human relations and training management. (Bakhısh, Trans.) tehran: Rouyan. persian

Gutek, B. B.-T. (1999). Distinguishing between service relationship and encounters. Journal of Applied Psychology, 84(2), 218-33. http://dx.doi.org/10.1037/0021-9010.84.2.218

John, O. a. (1993). Determin ants of Interjudge Agreement on Personality Traits: the Big-five Domains, Observability, Evaluativeness, and the Unique Perspective on the Self. Journal of Personality, 61(4), 521-51. http://dx.doi.org/10.1111/j.1467-6494.1993.tb00781.x

kalantari, k. (2010). Structural equation modeling in social - economic research. tehran: Publisher of Saba. persian 
Kinard, B. C. (2006). Relationship marketing: the influence of consumer involvement on perceived service benefits. Journal of Services Marketing, 20(6), 359-368. http://dx.doi.org/10.1108/08876040610691257

Leite, R. e. (2005). Women's satisfaction with physicians' communication s during an infertility consultation. Patient Education and Counseling, 59, 38-45. http://dx.doi.org/10.1016/j.pec.2004.09.006

PMid: 16198217

Lolli, J. (2012). Interpersonal communication skills and the young hospitality leader: Are they prepared? International Journal of Hospitality Management. http://dx.doi.org/10.1016/j.ijhm.2012.02.010

Lovelock, C. A. (2003). principles of marketing and services. (A. Tajzadeh, Trans.) Tehran: samt.persian

Matzler, K. R. (2011). Personality. International Journal of Human Resource Managemen, 22(2), 296-310.

Matzler.K. (2006). Methods and concepts in management: significance, satisfaction and suggestions for further research - perspectives from Germany, Austria and Switzerland. international Journal of Bank Marketing, 14(1), 1-13. http://dx.doi.org/10.1080/14783360600753653

Mehraban, h. (2000). Modirian communication skills and organizational commitment of teachers in secondary schools. mashhad: azad university. persian

Mittal, V. R. (1998). The asymmetric impact of negative and positive attribute-level performance on overall satisfaction and repurchase intentions. Journal of Marketing, 33-47. http://dx.doi.org/10.2307/1251801

Mooradian, T. R. (2006). Who trusts? Perso nality, trust and knowledge sharing. Management Learning, 37(4), 523-540. http://dx.doi.org/10.1177/1350507606073424

Nazarpour, c. (2005). The relationship between Personality traits and job satisfaction of teachers. Masjed Soleiman: khorasgan University. persian

Paul, P. (1996). Reading vocabulary knowledge and deafness. Journal of Deaf Studies \& Deaf Education. 1 (1). http://dx.doi.org/10.1093/oxfordjournals.deafed.a014279

Ramsey, R. a. (1997). Listening to your customer: the impact of perceived salesperson listening behavior on relationship outcomes. Journal of the Academy of Marketing Science, 127-137. http://dx.doi.org/10.1007/BF02894348

Shaw, J. (2006). Four core communication skills of highly effectivepractitioners. Vet Clin North Am Small Anim Pract, 385-96. http://dx.doi.org/10.1016/j.cvsm.2005.10.009

Suls, J. (1990). Medicine as a social science? Review of S. Spacapan and S. Oskamp (Eds.), The social psychology of health. Contemporary Psychology, 35, 657-658. 
Tajeddini, K. (2010). Effect of customer orientation and entrepreneurial orientation on innovativeness: Evidence from the hotel industry in Switzerland. Tourism Management, 31, 221-231. http://dx.doi.org/10.1016/j.tourman.2009.02.013

Vicent, R. \&. (1991). Achieving communication goals in relationships, The Multi-functionality of unward maintenance tactics. (3, Trans.)

Zamiri, n. (2009). Personality traits and quality of work life with fatigue in the South Oil National Company Staff. ahvaz: ahvaz Chamran University. persian

\section{Appendix}

Table 1. Extroversion and sociability definitions

\begin{tabular}{|c|c|c|}
\hline \multirow[b]{2}{*}{ Extroversion } & Extrovert people & $\begin{array}{l}\text { Sociable, affable, energetic, talkative people, and } \\
\text { accepting the society (Moradian, 2006; Ferguson, } \\
\text { 2009), love others, demand communities and } \\
\text { parties, active and like conversation (Costa } \\
\text { \&McCrae, 1992). }\end{array}$ \\
\hline & Introvert people & $\begin{array}{l}\text { Silent, introvert, self-collected, and cautious } \\
\text { people (Moradian, 2006; Ferguson, 2009). } \\
\text { Introverts are usually shy and prefer to be alone } \\
\text { (Costa \& McCrae, 1990). }\end{array}$ \\
\hline \multirow[b]{2}{*}{ Sociability } & $\begin{array}{l}\text { Interesting in communication with } \\
\text { others }\end{array}$ & $\begin{array}{l}\text { These people have a kind and clement heart (suls, } \\
\text { 1990; Ferguson, 2009). These people are } \\
\text { enthusiastic to help others and have this thought } \\
\text { about the others (Zamiri, 2009). These people } \\
\text { have a will of positive inter Personal relations and } \\
\text { also cooperative values (Digman, 1990). }\end{array}$ \\
\hline & $\begin{array}{l}\text { Lack of interesting in } \\
\text { communication with others }\end{array}$ & $\begin{array}{l}\text { Ego-centric, distrustful, and deceiver people } \\
\text { (Digman, 1990). Cold and violent, unkind, and } \\
\text { inflexible (Ferguson, 2009) }\end{array}$ \\
\hline
\end{tabular}


Table 2. Descriptive Statistics

\begin{tabular}{|l|l|c|c|}
\hline \multirow{4}{*}{ customers gender } & Category & Frequency & Percent \\
\hline \multirow{4}{*}{ service providers gender } & man & 153 & $\% 44.4$ \\
\cline { 2 - 4 } & woman & 192 & $\% 55.6$ \\
\hline & man & 254 & $\% 73.8$ \\
\cline { 2 - 4 } & woman & 91 & $\% 27.2$ \\
\hline \multirow{5}{*}{ Typtomers Education } & Diploma & 153 & $\% 44.4$ \\
\cline { 2 - 4 } & Above diploma & 122 & $\% 35.3$ \\
\cline { 2 - 4 } & MS & 35 & $\% 10.1$ \\
\cline { 2 - 4 } & Above MS & 14 & $\% 0.04$ \\
\cline { 2 - 4 } & PHD & 7 & $\% 0.02$ \\
\hline & General doctor & 123 & $\% 35.6$ \\
\cline { 2 - 4 } & & 51 & $\% 21.4$ \\
\cline { 2 - 4 } & Specialty doctor & 41 & $\% 11.8$ \\
\cline { 2 - 4 } & Education Consultant & 56 & $\% 16$ \\
\cline { 2 - 4 } & Familial Consultant & 51.7 \\
\cline { 2 - 4 } & Religious Consultant & & \\
\hline
\end{tabular}

Table 3. Measurement, source and Alpha coefficient variables

\begin{tabular}{|c|c|c|c|c|}
\hline Variable & measurement & $\begin{array}{l}\text { The number of } \\
\text { questions in the } \\
\text { questionnaire }\end{array}$ & $\begin{array}{l}\text { questions } \\
\text { Source }\end{array}$ & $\begin{array}{l}\text { Alpha } \\
\text { coefficient }\end{array}$ \\
\hline Friendship service & $\begin{array}{l}\text { Having the former information about } \\
\text { each customer, ability to establish the } \\
\text { friend service, ability to find common } \\
\text { points, ability to create adaptability }\end{array}$ & 4 & $\begin{array}{l}\text { Chris Linn } \\
\text { \& Hsieh, } \\
2011\end{array}$ & $\% 84.5$ \\
\hline $\begin{array}{l}\text { anticipation of } \\
\text { future interaction }\end{array}$ & $\begin{array}{l}\text { The anticipation of future interaction, } \\
\text { planning for future interaction, } \\
\text { enthusiasm to future interaction }\end{array}$ & 4 & $\begin{array}{l}\text { Chris Linn } \\
\text { \& Hsieh, } \\
2011\end{array}$ & $\% 79.1$ \\
\hline satisfaction & $\begin{array}{l}\text { Being satisfied with the presented } \\
\text { services, certainty in the correct } \\
\text { choice of the service provider }\end{array}$ & 3 & $\begin{array}{l}\text { Chris Linn } \\
\text { \& Hsieh, } \\
2011\end{array}$ & $\% 80.9$ \\
\hline Extroversion & Extroversion and introversion & 9 & $\begin{array}{l}\text { Costa and } \\
\text { MC Crea }\end{array}$ & $\% 72.3$ \\
\hline Sociability & $\begin{array}{l}\text { Interested or not interested in } \\
\text { communication }\end{array}$ & 12 & $\begin{array}{l}\text { Costa and } \\
\text { MC Crea }\end{array}$ & $\% 74.1$ \\
\hline $\begin{array}{l}\text { Communicational } \\
\text { skills }\end{array}$ & $\begin{array}{l}\text { The service provider's inclination to } \\
\text { talk to the customers, holding close } \\
\text { and intimate relationship }\end{array}$ & 3 & $\begin{array}{l}\text { Chris Linn } \\
\text { \& Hsieh, } \\
2011\end{array}$ & $\% 70.1$ \\
\hline
\end{tabular}




\section{Macrothink}

Table 4. The goodness indices of confirmatory factor analysis

\begin{tabular}{|c|c|c|c|c|c|c|c|c|c|c|}
\hline S CAIC & CAIC & S AIC & AIC & RFI & IFI & CFI & NNFI & NFI & AGFI & GFI \\
\hline 4311.43 & 1461.81 & 1806 & 1260.00 & 0.89 & 0.89 & 0.89 & 0.88 & 0.83 & 0.76 & 0.79 \\
\hline
\end{tabular}

Table 5. Standardized coefficients, significant and hypotheses results

\begin{tabular}{|l|l|l|l|l|}
\hline $\begin{array}{l}\text { Hypotheses } \\
\text { number }\end{array}$ & hypotheses & $\begin{array}{l}\text { standard } \\
\text { coefficient }\end{array}$ & T-Value & Result \\
\hline 1 & $\begin{array}{l}\text { the customer's extroversion has a significant positive effect } \\
\text { on the service provider's communicational skills. }\end{array}$ & 0.61 & 3.88 & Confirmation \\
\hline 2 & $\begin{array}{l}\text { customer's sociability has a significant positive effect on } \\
\text { the service provider's communicational skills. }\end{array}$ & -0.26 & -1.17 & Rejection \\
\hline 3 & $\begin{array}{l}\text { the social skills of the service providers have a significant } \\
\text { positive effect on the friendship service between the service } \\
\text { providers and the customer. }\end{array}$ & 0.7 & 6.38 & Confirmation \\
\hline 4 & $\begin{array}{l}\text { the service friendship between the customer and the service } \\
\text { provider has a positive significant effect on the customer's } \\
\text { satisfaction }\end{array}$ & 0.67 & 7.17 & Confirmation \\
\hline 5 & $\begin{array}{l}\text { the friendship service between the customer and the service } \\
\text { provider has a positive significant effect on the anticipation } \\
\text { of future interaction. }\end{array}$ & 0.07 & 0.8 & Rejection \\
\hline 6 & $\begin{array}{l}\text { the customer's satisfaction has a positive significant effect } \\
\text { on the anticipation of future interaction. }\end{array}$ & 0.74 & 7.84 & Confirmation \\
\hline
\end{tabular}

Table 6. Model goodness indices

\begin{tabular}{|l|l|l|l|}
\hline index & Value & index & Value \\
\hline Chi-square to degrees of freedom & 2.85 & AGFI & 0.76 \\
\hline RMSEA & 0.07 & GFI & 0.79 \\
\hline NFI & 0.83 & IFI & 0.90 \\
\hline NNFI & 0.89 & RFI & 0.81 \\
\hline PNFI & 0.76 & CFI & 0.90 \\
\hline
\end{tabular}

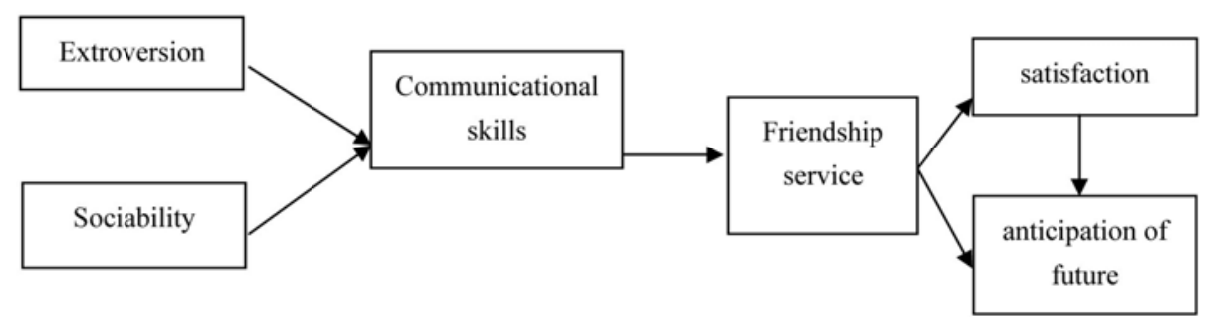

Figure 1. Conceptual model of research 


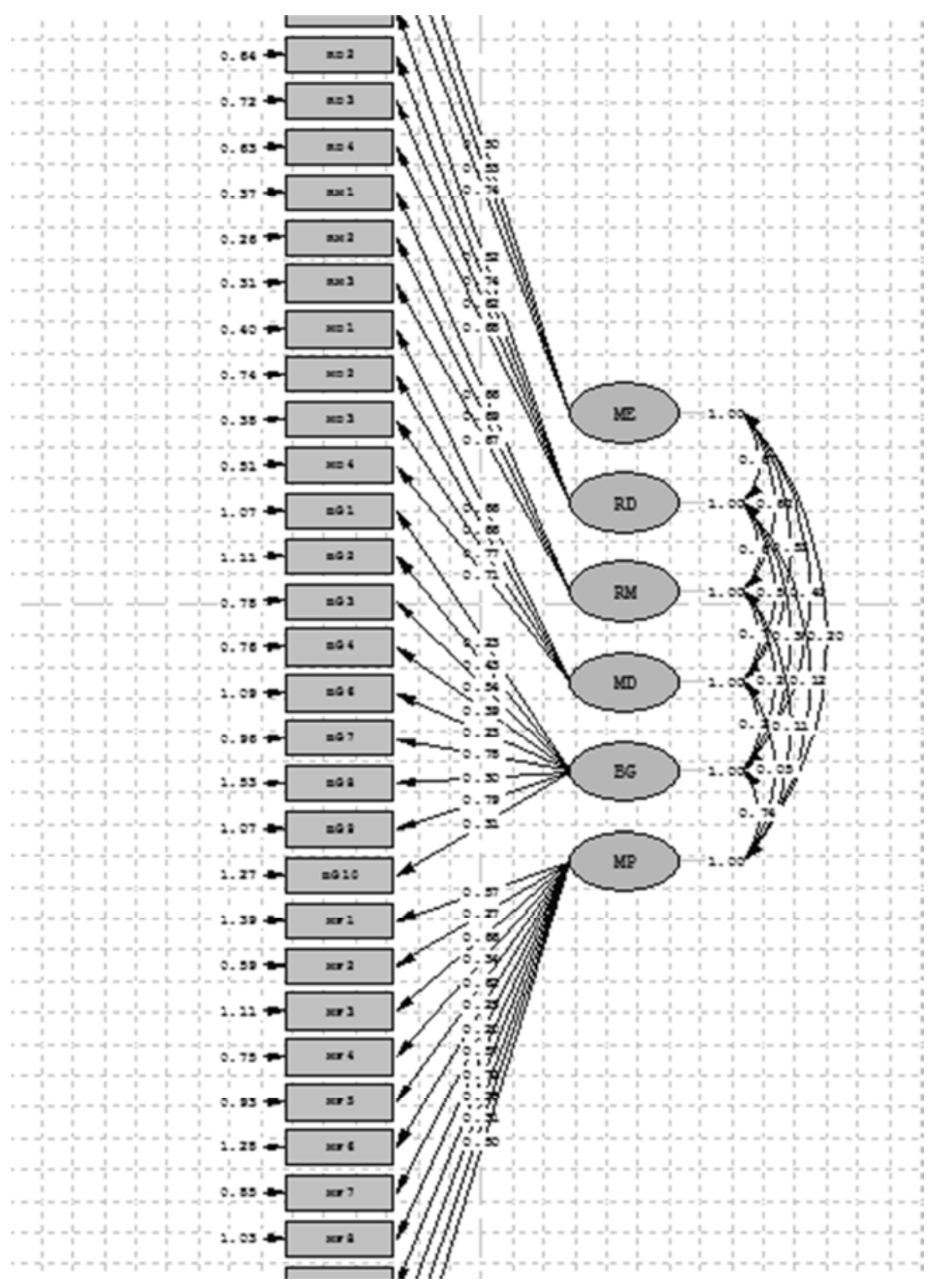




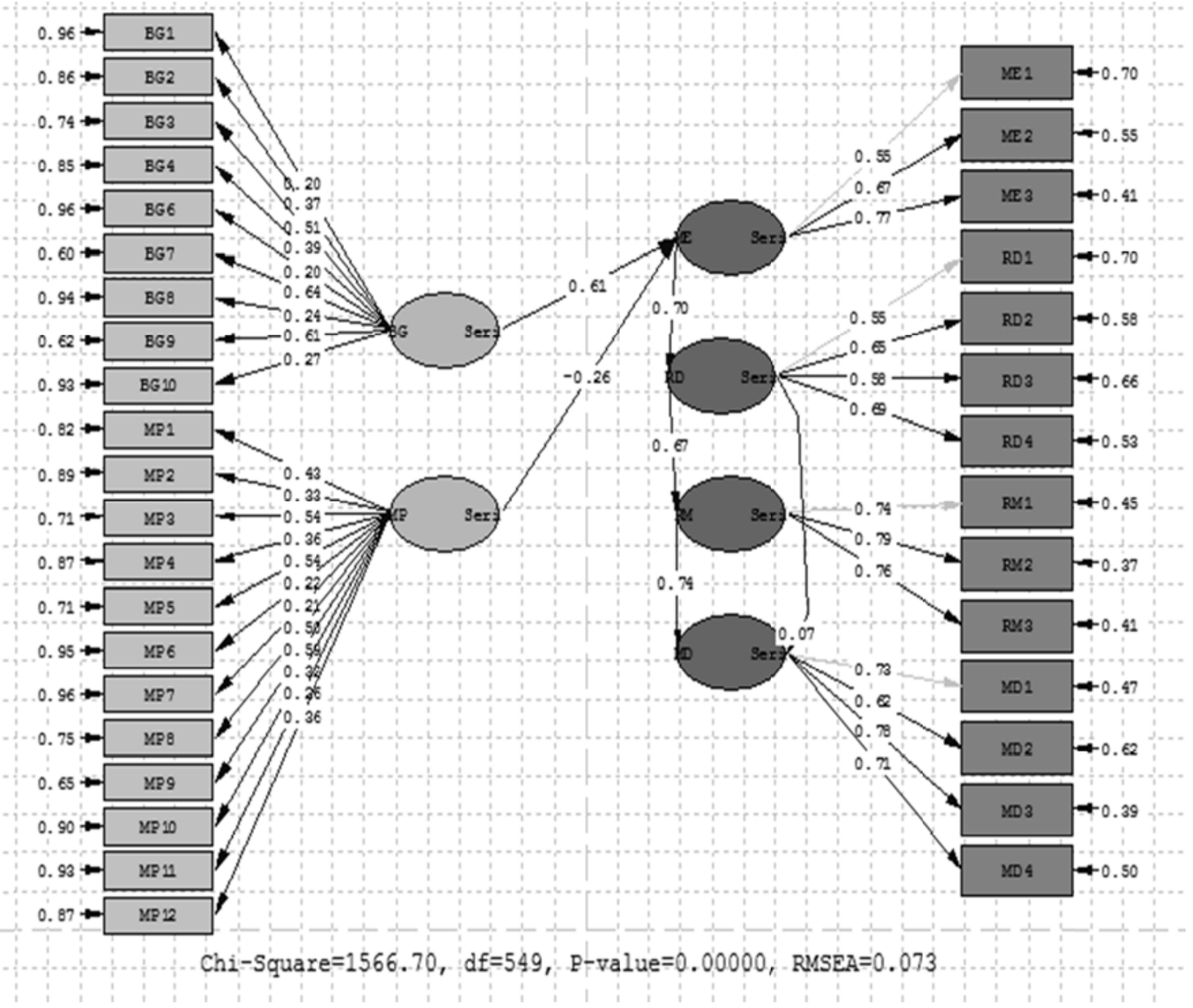




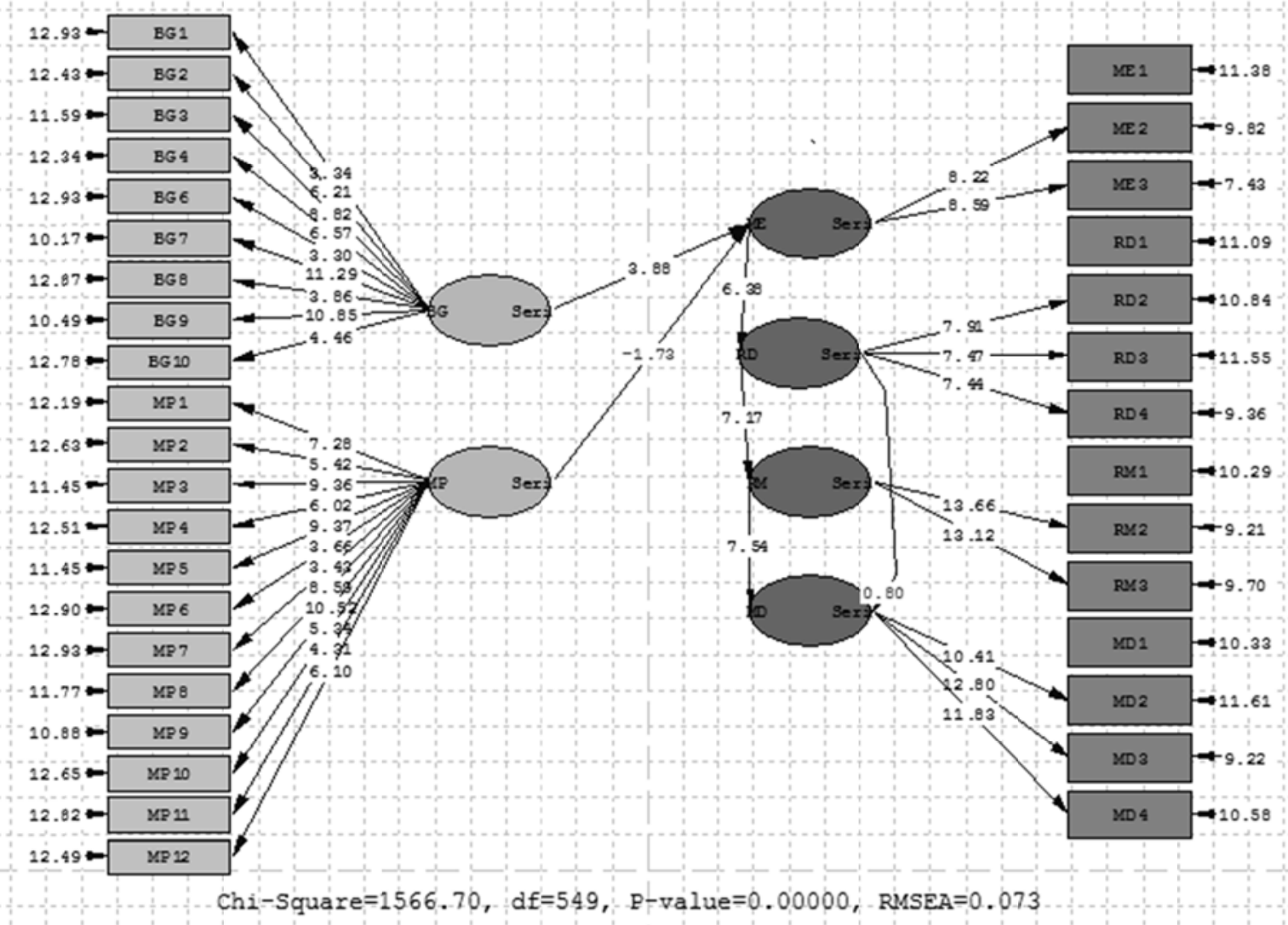

